\title{
PERAN SIKAP DALAM MEMEDIASI PENGARUH GAYA HIDUP TERHADAP MINAT BELI SMARTPHONE IPHONE DI KOTA DENPASAR
}

\author{
I Putu Febryantha Mantala ${ }^{1}$ \\ Gst. A. Kt. Gd. Suasana ${ }^{2}$ \\ ${ }^{1,2}$ Fakultas Ekonomi dan Bisnis Universitas Udayana, Bali, Indonesia \\ email: iputufebrymantala22@gmail.com
}

\begin{abstract}
ABSTRAK
Tujuan dari penelitian ini adalah untuk mengetahui peran sikap dalam memediasi pengaruh gaya hidup terhadap minat beli. Penelitian ini dilakukan di Kota Denpasar untuk mengetahui peran sikap dalam memediasi pengaruh gaya hidup terhadap minat beli smartphone Iphone. Jumlah Sampel yang diambil sebanyak 100 responden. Jumlah sampel ditetapkan sebanyak 100 orang responden dengan menggunakan teknik purposive sampling. Pengumpulan data dilakukan dengan penyebaran kuesioner dan data diukur dengan menggunakan skala 5 likert. Data dianalisis menggunakan teknik path analysis dan uji sobel. Hasil analisis menunjukkan bahwa gaya hidup berpengaruh signifikan terhadap minat beli, gaya hidup berpengaruh signifikan tehadap sikap, sikap berpengaruh signifikan terhadap minat beli, serta penelitian ini juga berhasil membuktikan bahwa gaya hidup berpengaruh signifikan terhadap minat beli yang dimediasi oleh sikap.
\end{abstract}

Kata kunci: minat beli, sikap, dan gaya hidup

\begin{abstract}
The purpose of this study was to determine the role of attitudes in mediating the influence of lifestyle on buying interest. This research was conducted in Denpasar City to determine the role of attitudes in mediating the influence of lifestyle on the interest in buying Iphone smartphones. The number of samples taken was 100 respondents. The number of samples was set as many as 100 respondents using purposive sampling technique. Data collection was carried out by distributing questionnaires and data was measured using a 5 likert scale. Data were analyzed using path analysis and sobel test techniques. The results of the analysis showed that lifestyle had a significant effect on buying interest, lifestyle had a significant effect on attitudes, attitude had a significant effect on buying interest, and this study also proved that lifestyle had a significant effect on purchase intention mediated by attitudes
\end{abstract}

Keywords: purchase intention, attitude, and lifestyle 
I Putu Febryantha Mantala, Peran Sikap dalam...

\section{PENDAHULUAN}

Teknologi diseluruh dunia semakin berkembang pesat, terutama di dunia komunikasi, sehingga batas antar benua seakan tidak berarti lagi. Perkembangan inovasi dalam alat komunikasi banyak membantu manusia mengerjakan sesuatu secara efektif dan efisien. Salah satu inovasi yang sudah mendunia dibidang komunikasi adalah ponsel pintar. Smartphone merupakan suatu inovasi dibidang telekomunikasi yang sangat membantu aktivitas manusia dan dipungkiri bahwa sudah menjadi kebutuhan pokok setiap orang di Indonesia (Pandu, 2017).

Lembaga riset Emarketer memperkirakan pada tahun 2018 jumlah pengguna aktif smartphone di Indonesia lebih dari 100 juta orang dan akan menjadi negara dengan pengguna aktif terbesar keempat di dunia setelah Cina, India, dan Amerika (http://teknologi.metrotvnews.com, 2016). Berbagai fasilitas yang ditawarkan oleh smartphone, untuk bersosialisasi di media sosial atau membantu dalam pekerjaan sehari-hari. Kemudahan-kemudahan yang ditawarkan juga menjadikan keberadaan smartphone dikalangan masyarakat merupakan suatu kebutuhan.

Kebutuhan akan smartphone tidak hanya menjadi sekedar alat komunikasi biasa, tetapi telah menjadi bagian dari gaya hidup. Gambar 1 menunjukkan bahwa pengguna aktif smartphone dari tahun ketahun semakin bertambah. 


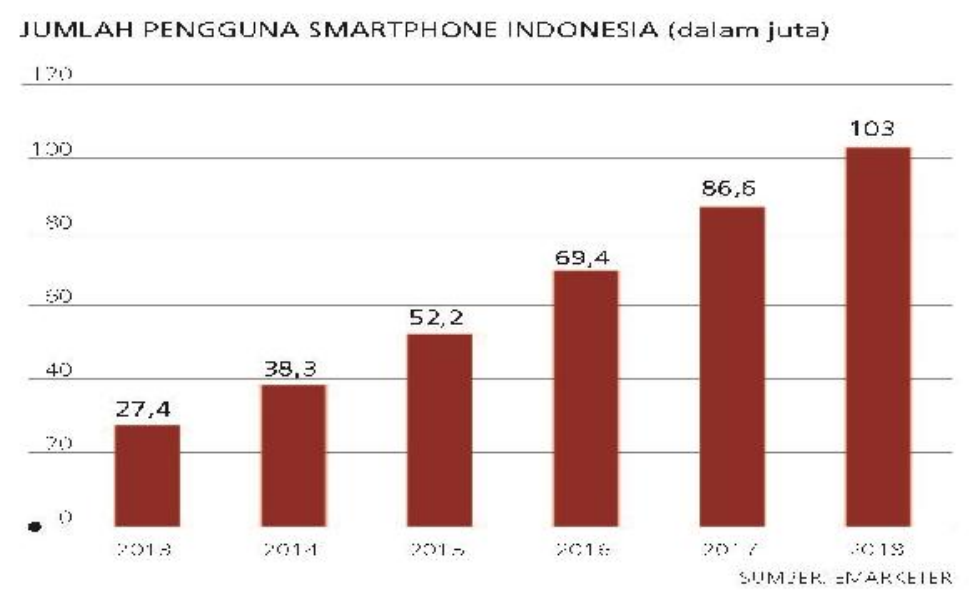

Gambar 1. Jumlah pengguna smartphone di Indonesia tahun 2013-2018

Pandu (2017) menyebutkan bahwa hampir semua lapisan masyarakat menggunakan smartphone dalam membantu aktifitas sehari-hari. Pertumbuhan smartphone di dunia termasuk Indonesia telah mampu merubah gaya hidup masyarakat. Masyarakat Indonesia khususnya yang hidup di wilayah perkotaan telah mengalami perubahan gaya hidup seiring dengan perkembangan teknologi informasi. Salah satu sarana komunikasi terkenal yang mampu merubah gaya hidup masyarakat Kota seperti misalnya di Kota Denpasar adalah smartphone dengan merek Iphone.

Syafrudin (2016) menyatakan Iphone merupakan salah satu smartphone terkenal di Indonesia dan selalu mengikuti trend dan gaya hidup pengguna. Kepemilikan Iphone sudah dianggap sebagai gaya hidup modern dan mewah terutama dikalangan menengah ke atas. Aplikasi yang ditawarkan Iphone menambah kesan bahwa merek produk tersebut terkenal dan sesuai dengan kebutuhan masyarakat. Iphone memiliki design yang minimalis dan sederhana, memiliki layar sentuh dan satu tombol "home", sehingga tampak elegan 
I Putu Febryantha Mantala, Peran Sikap dalam...

(Saputra dkk., 2017). Iphone merupakan smartphone pertama yang menggunakan fitur multi-touch. Multi-touch adalah metode input layar sentuh yang memungkinkan penggunaan dua atau lebih jari pada waktu yang bersamaan. Iphone juga memiliki beberapa fungsi pendukung lainnya sesuai dengan spesifikasi terpasang.

Iphone memperkenalkan multi-touch ke Dunia smartphone yang memungkinkan pinching dan stretching gestures pada layar untuk mengontrol zoom. Konsumen juga dapat dengan mudah melakukan instalasi perangkat lunak melalui unduhan yang di inginkan Apple Store. Smartphone Iphone terkenal mahal walaupun demikian masih banyak orang tetap membeli smartphone tersebut untuk memenuhi gaya hidup.

Gaya hidup dapat menggambarkan perilaku seseorang tentang bagaimana menggunakan uang dan memanfaatkan waktu yang dimilikinya (Sumarwan, 2002). Gaya hidup adalah pola hidup seseorang dalam dunia kehidupan sehari-hari yang dinyatakan dalam aktivitas, minat dan pendapat (opini) yang bersangkutan terhadap keberadaan suatu produk (Syafrudin, 2016). Menurut Sutisna (2010:145), gaya hidup dapat diidentifikasikan dengan bagaimana pola kehidupan seseorang dalam menghabiskan waktu (aktivitas), minat (ketertarikan), dan perilakunya pada kegiatan sehari-hari.

Gaya hidup konsumen pada dasarnya dapat digunakan sebagai sarana pengambilan keputusan. Gaya hidup cenderung mengklasifikasikan konsumen berdasarkan dimensi AIO yaitu : aktivitas, minat (interest) dan opini (pandanganpandangan) dalam melakukan analisis suatu peristiwa yang terjadi pada lingkungan 
sekitar (Syafrudin, 2016). Seseorang dapat menggunakan konsep gaya hidup untuk menganalisis peristiwa di lingkunagnnya dan menafsirkan atau meramalkan peristiwa-peritiwa tersebut sebagai suatu dorongan pribadi.

Gaya hidup, seperti dijelaskan sebelumnya memunculkan sikap positif bagi pengguna Iphone terutama terkait dengan manfaat yang dirasakan. Manfaat dimaksud sepeti kebutuhan akan internet, media sosial, dan pengiriman data. Masyarakat penguuna seluler dihadapkan pada berbagai merek smartphone terkenal, walaupun demikian minat beli terhadap Iphone tetap merupakan pilihan yang utama. Hal tersebut disebabkan karena Iphone memiliki inovasi dalam design dan fitur yang sesuai dengan kebutuhan pengguna. Gaya hidup dapat mendorong sikap seseorang di dalam mkemilih dan membeli suatu produk smartphone. (Sangadji dan Sopiah 2013) menyatakan bahwa sikap adalah inti dari perasaan suka atau tidak suka seseorang terhadap suatu objek.

Sikap merupakan konsep paling penting bagi pemasar untuk memenuhi kebutuhan konsumen. Mowen dan Minor (2002), mengatakan sikap (attitude) sebagai afeksi atau perasaan terhadap sebuah rangsangan. Suprapti (2010:136), menyatakan sikap konsumen terhadap suatu objek adalah berupa tendensi atau kecenderungan yang dipelajari untuk mengevaluasi objek dalam suatu cara yang menyenangkan atau tidak menyenangkan secara konsisten. Menurut Schiffman dan Kanuk (2007:222), sikap adalah kecenderungan belajar untuk berperilaku dengan cara yang konsisten atau tidak mengenai suatu objek. Artinya, konsumen yang suka atau bersikap positif terhadap suatu produk akan selalu memiliki keinginan yang kuat untuk membeli produk tersebut begitupun sebaliknya. 
Dimensi sikap yang perlu diperhatikan adalah kepercayaan (kognitif), emosi (afektif), dan keinginan berperilaku (konatif). Gaya hidup dan sikap konsumen apabila digunakan oleh pemasar secara cermat, maka akan dapat membantu memahami nilai-nilai konsumen yang terus berubah dan bagaimana nilai tersebut akan mempengaruhi niat pembelian konsumen (Suraputra, 2017). Smartphone Iphone identik dengan harga yang relatif mahal dan perawatannya yang cukup mahal. Hal ini menunjukkan bahwa minat beli konsumen dalam membeli bukan hanya mengacu pada pertimbangan ekonomis semata, tetapi lebih berorientasi pada seberapa besar fungsi, nilai kepuasan serta bagaimana suatu produk dapat mewakili kebutuhannya. (http://teknologi.metrotvnews.com, 2016).

Minat beli (purchace intention) berhubungan dengan rencana konsumen untuk membeli, serta berapa banyak unit produk atau jasa yang dibutuhkan pada periode tertentu (Kumala, 2012). Lebih lanjut dinyatakan bahwa, minat beli merupakan instruksi diri konsumen untuk melakukan pembelian atas suatu produk, melakukan perencanaan, mengambil tindakan-tindakan yang relevan seperti mengusulkan, dan akhirnya mengambil keputusan untuk melaukan pembelian.

Minat beli adalah evaluasi dan sikap konsumen terhadap produk dengan mempertimbangkan faktor eksternal, sehingga berdampak pada kesediaan konsumen untuk membeli produk (Wen dan Li, 2013). Minat pembelian adalah niat untuk melakukan pembelian pada kesempatan mendatang (Indriani dan Hendriati, 2009). Jadi, minat pembelian terhadap Iphone yang timbul pada benak konsumen bukan hanya didasarkan pada pertimbangan gaya hidup saja, tetapi juga dorongan 
dari faktor sikap. Smartphone Iphone dapat mewakili gaya hidup masa kini karena memiliki fitur yang sesuai dengan kebutuhan.

Survei awal yang dilakukan terhadap 20 orang masyarakat Kota Denpasar, di temukan bahwa 60 persen atau lebih memilih smartphone Iphone dengan alasan fitur yang lebih baik dan mengikuti gaya hidup masa kini dan mencerminkan kelas sosial. Dan sisanya, 40 persen memilih merek lain merek lain dengan alasan harga yang relatife terjangkau. Study empiris menunjukkan bahwa, gaya hidup berpengaruh positif dan signifikan terhadap niat pembelian sepeda motor sport Honda di Kota Denpasar (Suraputra dan Warmika, 2017). Peneliti lain, Latifah dkk. (2017) menyatakan bahwa gaya hidup berpengaruh negatif dan signifikan terhadap sandal dan sepatu bata Cabang di Kuningan Jakarta. Perbedaan penelitian tersebut mungkin di sebabkan karna faktor sikap sebagai mediasi dan hal tersebut di dukung oleh penelitian Qing et al. (2012).

Fenomena seperti yang dijelaskan diatas tercermin adanya research gap, antara pengaruh gaya hidup terhadap minat beli konsumen. Berdasarkan uraian tersebut maka penelitian ini penting dilakukan untuk membuktikan pengaruh antara kedua variabel tersebut, dikaitkan dengan faktor sikap sebagai variabel mediasi. Penelitian dilakukan di Kota Denpasar dengan subjek penelitian pengguna smartphone merek Iphone merupakan salah satu Kota dengan penduduk terpadat di Bali memiliki jumlah penduduk mencapai angka 1.102.203 jiwa pada tahun 2016 (www.denpasarKota.go.id). Bali.bps.go.id (2015) mencatat Kota Denpasar memiliki pertumbuhan ekonomi tertinggi di Bali. Gaya hidup masyarakat Kota Denpasar mencerminkan masyarakat yang update akan kebutuhan produk-produk 
baru, terutama produk elektronik termasuk smartphone sebagai alat bantu seharihari.

Minat beli adalah tahap kecenderungan konsumen untuk bertindak sebelum benar-benar melakukan pembelian dan terdapat perbedaan antara pembelian aktual dan kecenderungan pembelian. Pembelian aktual, yaitu pembelian yang benarbenar dilakukan oleh konsumen sedangkan kecenderungan pembelian merupakan sebuah niat yang timbul pada konsumen untuk melakukan pembelian pada waktu yang akan datang. Minat beli adalah jenis keputusan yang pada khususnya mempelajari mengapa pelanggan membeli merek tertentu. Konstruksi seperti mengingat sesuatu, membeli merek, dan mengantisipasi untuk membeli merek membantu untuk memberikan niat pembelian (Porter, 1974). Barr (2007) menyatakan niat beli adalah keinginan untuk memiliki produk, niat beli akan timbul apabila seorang konsumen sudah terpengaruh terhadap mutu dan kualitas dari suatu produk serta informasi seputar produk.

Schiffman dan Kanuk (2007:227) berpendapat niat beli merupakan pernyataan maksud konsumen untuk membeli. Skala maksud pembeli digunakan untuk menilai kemungkinan konsumen untuk membeli suatu produk atau berprilaku menurut cara tertentu. Niat beli adalah evaluasi dan sikap konsumen terhadap produk dengan melihat faktor eksternal, sehingga berdampak pada kesediaan konsumen untuk membeli produk (Wen dan Li, 2013).

Mowen dan Minor (2012) menyebutkan bahwa istilah pembentukan sikap konsumen (costumer attitude formation) sering kali menggambarkan hubungan antara kepercayaan, sikap, dan perilaku. Maka dari itu, terdapat suatu ketertarikan 
antara kepercayaan, sikap, dan perilaku yang memiliki hubungan dengan bagaimana penilaian yang diberikan oleh konsumen terhadap atribut suatu produk dimana atribut suatu produk merupakan salah satu karakteristek dari suatu produk.

Menurut Leeraphong dan Mardjo (2013) sikap merupakan kecendrungan terhadap produk tertentu yang menyebabkan konsumen merespon baik atau tidak baik terhadap produk tertentu. Sikap juga merupakan salah satu konsep yang paling penting digunakan pemasar untuk memahami konsumen (Setiadi, 2003). Berdasarkan beberapa definisi sikap, bahwa sikap merupakan pencerminan seseorang terhadap suatu objek yang dapat mempengaruhi perilakunya terhadap objek tersebut.

Menurut Schiffman dan Kanuk (2007:222) sikap adalah kecenderungan belajar untuk berperilaku dengan cara yang konsisten atau tidak, sehubungan dengan objek tertentu. Definisi lain mengenai sikap disampaikan oleh Severin dan Tankard (2009:179) adalah sistem evaluasi positif atau negatif yang awet, perasaan-perasaan emosional dan tendensi tindakan pro atau kontra terhadap sebuah objek sosial. Sikap adalah mempelajari kecendrungan memberikan tanggapan terhadap suatu objek, baik disenangi ataupun tidak disenangi secara konsisten (Setiadi, 2010:214).

Gaya hidup menurut Widjaja (2011), merupakan perilaku individu yang diwujudkan dalam bentuk aktivitas, minat, dan pandangan individu untuk mengaktualisasikan kepribadiannya karena pengaruh interaksi dengan lingkungannya. Berdasarkan definisi tersebut di atas, maka dapat diartikan bahwa 
gaya hidup, yaitu pola individu dalam mengekspresikan minat, opini, kegiatan dan tingkat individu dalam mengkonsumsi suatu produk.

Gaya hidup menggambarkan "keseluruhan diri seorang" yang berinteraksi dengan lingkungannya. Cristianus (2017) membuktikan bahwa gaya hidup berpengaruh positif dan signifikan terhadap minat beli smartphone Xiomi. Yuliana (2011) menemukan bahwa gaya hidup memiliki pengaruh positif dan signifikan terhadap niat yang akan menghasilkan keputusan pembelian. Qing et al. (2012) menyatakan bahwa niat pembelian konsumen terhadap buah segar impor di China secara positif dan signifikan dipengaruhi oleh gaya hidup.

Indrayani dan Nurcahya (2014) juga membuktikan bahwa terdapat pengaruh positif dan signifikan antara variabel gaya hidup dan niat beli pada handphone Samsung Galaxy di Kota Denpasar. Gaya hidup secara positif dan signifikan berpengaruh terhadap niat beli sepeda motor Vespa Piaggio (Kusuma dan Suparna, 2015).

$\mathrm{H}_{1}$ : Gaya hidup berpengaruh positif dan signifikan terhadap minat beli

Kotler dan Amstrong (2010) menyatakan bahwa faktor-faktor yang mempengaruhi gaya hidup seseorang ada dua, yaitu faktor yang berasal dari dalam diri individu (internal) dan faktor yang berasal dari luar (eksternal). Faktor internal, salah satunya adalah sikap Sikap bisa dipahami sebagai cara seseorang dalam memberikan tanggapan terhadap suatu hal sesuai dengan keadaan jiwa dan pikirannya yang dipengaruhi oleh pengalaman dan mempengaruhi secara langsung perilaku orang tersebut. Sikap bisa jadi dipengaruhi oleh tradisi, kebiasaan, kebudayaan, dan lingkungan sosialnya. 
Fahrozi (2015) menyatakan bahwa gaya hidup memiliki pengaruh positif yang signifikan terhadap sikap atas uang oleh kalangan muda pada Coffee Shop di Pekanbaru. Qing et al. (2012) membuktikan bahwa gaya hidup berpengaruh positif dan signifikan terhadap sikap konsumen terhadap buah segar di China. Gaya hidup seseorang dapat diidentifikasi dari perilaku orang tersebut seperti kegiatan-kegiatan dalam pengambilan keputusan, cara mendapatkan, dan mempergunakan suatu barang atau jasa. Nurlaily dan Noermijati (2017) gaya hidup memiliki pengaruh positif dan signifikan terhadap sikap konsumen. Gaya hidup berpengaruh positif terhadap sikap membeli di media sosial (online). Gaya hidup dan sikap konsumen secara bersama-sama mempunyai pengaruh yang signifikan terhadap keputusan pembelian produk kosmetik Pond's pada mahasiswa prodi pendidikan ekonomi STKIP PGRI Sumatera Barat (Fitriani, dkk 2013).

$\mathrm{H}_{2}$ : Gaya hidup berpengaruh positif dan signifikan terhadap sikap konsumen.

Qing et al. (2012) dalam penelitiannya menyatakan bahwa adanya hubungan yang positif signifikan antara sikap terhadap niat pembelian untuk produk buahbuahan import dan lokal. Sigit (2006) yang meneliti tentang minat beli pasta gigi Close-Up pada mahasiswa Universitas Islam Indonesia yang dipengaruhi oleh sikap menemukan bahwa sikap berpengaruh positif dan signifikan terhadap niat beli.

Nasehifar dan Haghi (2014) menemukan hasil bahwa terdapat hubungan signifikan dan positif antara sikap dan niat beli. Penelitian tersebut sejalan dengan Roselina dan Nurcaya (2012) menunjukkan bahwa variabel sikap berpengaruh signifikan terhadap niat beli Mobil Toyota Agya di Kota Denpasar. Dalam 
penelitian ini, atribut-atribut pembentuk sikap yang dijadikan ukuran, yaitu desain mobil, citra merek atau brand, harga mobil, dan pilihan warna mobil.

Perusahaan perlu mengetahui bagaimana konsumen memandang produk dan program pemasaran dari perusahaan itu sendiri. Tanggapan konsumen terhadap produk yang dihasilkan suatu perusahaan sangat penting untuk diketahui termasuk didalamnya penilaian konsumen mengenai atribuut-atribut produk tersebut. Xie dan Chaipoopirutana (2014) menghasilkan temuan bahwa sikap konsumen memeiliki mpengaruh signifikan dan positif terhadao niat beli product smartphone merek Xiomi. Sikap berpengaruh positif dan signifikan terhadap niat pembelian sepeda motor sport Honda di Kota Denpasar (Suraputra, 2017).

$\mathrm{H}_{3}$ : Sikap berpengaruh positif dan signifikan terhadap minat beli.

Tonget al. (2015) dalam penelitiannya menyatakan bahwa sikap dapat memediasi secara positif dan signifikan hubungan antara gaya hidup terhadap niat pembelian produk hijau dan halal di Malaysia. Penelitian tersebut sejalan dengan Qing et.al (2012) dalam penelitiannya menyatakan bahwa niat pembelian konsumen terhadap buah segar di China dipengaruhi oleh kelompok-kelompok gaya hidup dan peran sikap dalam memediasi juga memberikan pengaruh positif terhadap niat beli konsumen untuk buah segar di China. Semakin besar peran gaya hidup seseorang maka niat pembeliannya akan semakin tinggi dan dengan adanya mediasi dari sikap, maka konsumen hal tersebut dapat memberikan dorongan terhadap konsumen untuk lebih memperkuat dalam melakukan keputusan pembelian. 
Sikap memediasi pengaruh harga dengan niat beli Smartphone merek Samsung di kalangan remaja di Kota Denpasar (Putra dan Sudiksa, 2016). Suraputra dan Warmika (2017) mengatakan gaya hidup melalui mediasi sikap konsumen berpengaruh positif dan signifikan terhadap niat pembelian sepeda motor sport Honda di Kota Denpasar.

$\mathrm{H}_{4}$ : Sikap berpengaruh positif dan signifikan dalam memediasi gaya hidup terhadap minat beli.

\section{METODE PENELITIAN}

Penelitian ini dilakukan di Kota Denpasar dengan alasan Kota Denpasar merupakan ibu Kota Provinsi Bali dan memiliki jumlah penduduk terbanyak di bandingkan dengan kabupaten lain di Bali. Variabel dalam penelitian ini yaitu gaya hidup $(\mathrm{X})$ dengan satu variabel terikat yaitu minat beli $\left(\mathrm{Y}_{2}\right)$ dan variabel mediasi, yaitu sikap $\left(\mathrm{Y}_{1}\right)$.

Populasi dalam penelitian ini bersifat infinite (tidak terbatas). Sampel dalam penelitian ini adalah konsumen yang akan melakukan pembelian smartphone Iphone. Roscoe dalam Sekaran (2003), mengemukakan ukuran sampel yang baik adalah 5 - 10 kali jumlah variabel atau indikator dalam penelitian. Penelitian ini menggunakan 19 indikator sehingga jumlah sampel yang dapat di gunakan berkisar 19 × $5=95$ hingga 19 x $10=190$ responden . Untuk memperoleh hasil yang baik jadi jumlah sampel yang di gunakan dalam penelitian ini sebanyak 100 responden. Ukuran sampel tersebut sudah termasuk dalam rentang 95 sampai 190 sampel yang diestimasi. Teknik penentuan sampel yang digunakan pada penelitian ini adalah non probability sampling dengan 
metode purposive sampling, yaitu sampel ditentukan dengan pertimbangan tertentu. Metode pengumpulan data dalam penelitian ini adalah dengan metode survey menggunakan kuesioner. Selanjutnya butir-butir pertanyaan diukur dengan skala Likert.

Tabel 1.

Variabel dan Indikator

\begin{tabular}{|c|c|c|c|c|}
\hline No & Variabel & Indikator & $\begin{array}{c}\text { Instrumen } \\
\text { Variabel }\end{array}$ & Sumber \\
\hline 1 & $\begin{array}{c}\text { Minat Beli } \\
\left(\mathrm{Y}_{2}\right)\end{array}$ & $\begin{array}{l}\text { 1. Minat beli } \\
\text { transaksional }\left(\mathrm{Y}_{2.1}\right) \\
\text { 2. Minat beli referensial } \\
\left(\mathrm{Y}_{2.2}\right) \\
\text { 3. Minat beli } \\
\text { preferensial }\left(\mathrm{Y}_{2.3}\right) \\
\text { 4. Minat beli eksploratif } \\
\left(\mathrm{Y}_{2.4}\right)\end{array}$ & & $\begin{array}{l}\text { Ferdinand, } \\
2002\end{array}$ \\
\hline 2 & Sikap $\left(\mathrm{Y}_{1}\right)$ & $\begin{array}{l}\text { 1. Merek produk }\left(\mathrm{Y}_{1.1}\right) \\
\text { 2. Pengetahuan manfaat } \\
\text { produk }\left(\mathrm{Y}_{1.2}\right) \\
\text { 3. Perasaan sekarang } \\
\text { terhadap produk } \\
\left(\mathrm{Y}_{1.3}\right) \\
\end{array}$ & & $\begin{array}{l}\text { Setiadi, } \\
2003\end{array}$ \\
\hline \multirow{3}{*}{3} & \multirow{3}{*}{$\begin{array}{l}\text { Gaya hidup } \\
\text { (X) }\end{array}$} & 1. Aktivitas (X.1) & $\begin{array}{l}\text { - Bekerja (X.1.1) } \\
\text { - Hobi (X.1.2) } \\
\text { - Kegiatan social } \\
\quad \text { X.1.3) } \\
\text {-Komunitas (X.1.4) } \\
\text { - Belanja (X.1.5) }\end{array}$ & \multirow{3}{*}{$\begin{array}{l}\text { Setiadi, } \\
2010\end{array}$} \\
\hline & & 2. Minat $\left(X_{.2}\right)$ & $\begin{array}{l}\text { - Keluarga (X.2.1) } \\
\text { - Rumah (X.2.2) } \\
\text { - Fashion (X.2.3) } \\
\text { - Media (X.2.4) }\end{array}$ & \\
\hline & & 3. Opini (X.3) & $\begin{array}{l}\text {-Terhadap diri } \\
\text { sendiri (X.3.1) } \\
\text { - Ekonomi (X.3.1) } \\
\text {-Masa depan } \\
\text { (X.3.3) }\end{array}$ & \\
\hline
\end{tabular}

Sumber : Data diolah, 2018

Teknik analisis data yang digunakan adalah analisis jalur. Analisis jalur digunakan untuk menentukan pola hubungan antara tiga atau lebih dan tidak dapat 
digunakan untuk mengkonfirmasi atau menolak hipotesis, (Aprilsya, 2016). Riduwan dan Kuncoro (2011:2) menyatakan analisis jalur digunakan untuk menganalisis pola hubungan antar variabel dengan tujuan untuk mengetahui pengaruh langsung maupun tidak langsung seperangkat variabel bebas terhadap variabel terikat.

Pengujian hipotesis mediasi dapat dilakukan dengan prosedur yang dikembangkan oleh Sobel (1982) dan dikenal dengan Uji Sobel (Sobel Test). Uji sobel digunakan untuk menguji kekuatan pengaruh tidak langsung variabel gaya hidup $(\mathrm{X})$ ke variabel minat beli $\left(\mathrm{Y}_{2}\right)$ melalui variabel sikap $\left(\mathrm{Y}_{1}\right)$. Pengaruh tidak langsung gaya hidup $(\mathrm{X})$ terhadap variabel minat beli $\left(\mathrm{Y}_{2}\right)$ melalui variabel sikap (X) dihitung dengan mengalikan koefisien jalur $\mathrm{X}$ terhadap $\mathrm{Y}_{1}$ (a) dengan koefisien jalur $Y_{1}$ terhadap $Y_{2}(b)$ atau ab. Standard error koefisien a dan b ditulis dengan $S_{a}$ dan $\mathrm{S}_{\mathrm{b}}$, besarnya standard error tidak langsung (indirect effect) $\mathrm{S}_{\mathrm{ab}}$

\section{HASIL DAN PEMBAHASAN}

Data penelitian diperoleh dari hasil kuesioner yang telah disebarkan kepada responden penelitian sejumlah 100 orang pengguna smartphone Iphone di kota Denpasar.

Karakteristik responden yang ditinjau dari jenis kelamin, usia, dan pendidikan terakhir. Responden dengan jenis kelamin perempuan memiliki presentase tertinggi yaitu 68 persen, sedangkan responden kelamin laki-laki hanya memiliki presentasi yaitu 32 persen. Kemudian responden terbanyak dengan presentase 62 persen diperoleh dengan rentang usia 22-26 tahun. Setelah itu, diikuti oleh responden yang berusia 18-21 tahun dengan jumlah presentase sebesar 18 persen pada tingkat 
kedua. Peringkat ketiga responden dengan usia 27-31 tahun terdapat jumlah presentase sebesar 13 persen. Peringkat ke empat yaitu responden usia 32-36 tahun dengan presentase 4 persen dan responden dengan peringkat kelima yaitu responden usia 37-42 tahun dengan presentase sebesar 3 persen.

Selain itu, pendidkan terakhir responden memperlihatkan bahwa responden di dominasi oleh Mahasiswa/i (S1) sebesar 51 persen dan selanjutnya di ikuti oleh responden tingkat Diploma sebesar 21 persen. Pelajar menempati posisi ketiga sebesar 17 persen dan posisi keempat yaitu Mahasiswa/i (S2) sebesar 11 persen. Hal ini mengindikasikan bahwa pelajar ataupun mahasiswa leibih mengikuti gaya hidup jaman sekarang dengan menyikapi produk-produk yang sedang ngetren di kalangannya sehingga menimbulkan minat beli yang tinggi

Perhitungan koefisien path dilakukan dengan analisis regresi melalui software SPSS, diperoleh hasil yang ditunjukan pada Tabel 3 berikut :

Tabel 2.

Hasil Analisis Jalur Struktur 1

\begin{tabular}{|c|c|c|c|c|c|}
\hline & \multicolumn{2}{|c|}{$\begin{array}{c}\text { Unstandardized } \\
\text { Coefficients }\end{array}$} & \multirow{2}{*}{$\begin{array}{c}\text { Standardized } \\
\text { Coefficients } \\
\text { Beta }\end{array}$} & \multirow[b]{2}{*}{$\mathbf{T}$} & \multirow[b]{2}{*}{ Sig. } \\
\hline & B & Std. Error & & & \\
\hline (Constant) & .668 & .829 & & .805 & .423 \\
\hline Gaya Hidup & .234 & .018 & .793 & 12.893 & .000 \\
\hline F Hitung & & & & & 166,220 \\
\hline Signifikansi & & & & & 0,000 \\
\hline $\mathrm{R}_{1}$ Square & & & & & 0,629 \\
\hline Adjusted $R_{1}$ Square & & & & & 0,625 \\
\hline
\end{tabular}

Sumber: Data diolah, 2018

Berdasarkan Tabel 2 hasil analisis jalur substruktur satu seperti yang disajikan pada Tabel 4.8, maka persamaan strukturalnya adalah sebagai berikut :

$$
\begin{aligned}
\mathrm{Y}_{1} & =\beta_{1} \mathrm{X}+\mathrm{e}_{1} \ldots \\
\mathrm{Y} 1 & =0,793 \mathrm{X}+\mathrm{e}_{1}
\end{aligned}
$$


Tabel Hasil 3.

Analisis Jalur Struktur 2

\begin{tabular}{|c|c|c|c|c|c|}
\hline & \multicolumn{2}{|c|}{$\begin{array}{c}\text { Unstandardized } \\
\text { Coefficients }\end{array}$} & \multirow{2}{*}{$\begin{array}{l}\text { Standardized } \\
\text { Coefficients } \\
\text { Beta }\end{array}$} & \multirow[b]{2}{*}{$\mathbf{T}$} & \multirow[b]{2}{*}{ Sig. } \\
\hline & B & Std. Error & & & \\
\hline (Constant) & 1.138 & .848 & & 1.343 & .182 \\
\hline Gaya Hidup & .242 & .030 & .682 & 7.959 & .000 \\
\hline Sikap & .251 & .103 & 209 & 2.440 & .017 \\
\hline F Hitung & & & & & 134,936 \\
\hline Signifikansi & & & & & 0,000 \\
\hline $\mathrm{R}_{2}$ Square & & & & & 0,736 \\
\hline Adjusted $R_{2}$ Square & & & & & 0,730 \\
\hline
\end{tabular}

Berdasarkan Tabel 3. hasil analisis jalur substruktur dua seperti yang disajikan pada Tabel 3, maka persamaan strukturalnya adalah sebagai berikut :

$$
\begin{array}{r}
\mathrm{Y}_{2}=\beta_{2} \mathrm{X}+\beta_{3} \mathrm{Y}_{1}+\mathrm{e}_{2} \ldots \ldots \ldots \ldots \ldots \ldots \\
\mathrm{Y} 2=0,682 \mathrm{X}+0,209 \mathrm{Y}_{1}+\mathrm{e}_{2}
\end{array}
$$

Menguji nilai koefisien determinasi $\left(\mathrm{R}^{2}\right)$ dan variabel error (e) berdasarkan model substruktur satu dan substruktur dua, maka dapat disusun model diagram jalur akhir. Sebelum menyusun model diagram jalur akhir, terlebih dahulu dihitung nilai standar eror sebagai berikut:

$P e_{i}=\sqrt{1-R_{i}^{2}}$

Substruktur 1:

$\mathrm{Y} 1=0,793 \mathrm{X}+\mathrm{e}_{1}$

Pengaruh error $\left(\mathrm{Pe}_{1}\right)=\sqrt{1-R_{1}{ }^{2}}$

$\mathrm{Pe}_{1}=\sqrt{1-0,629}=\sqrt{0,371}=0,609$

Substruktur 2:

$\mathrm{Y} 2=0,682 \mathrm{X}+0,209 \mathrm{Y} 1+\mathrm{e}_{2}$

Pengaruh error $\left(\mathrm{Pe}_{2}\right)=\sqrt{1-R_{2}{ }^{2}}$ 
$\mathrm{Pe}_{2}=\sqrt{1-0,736}=\sqrt{0,264}=0,514$

Berdasarkan perhitungan pengaruh error (Pei), didapatkan hasil pengaruh error $\left(\mathrm{Pe}_{1}\right)$ sebesar 0,609 dan pengaruh error $\left(\mathrm{Pe}_{2}\right)$ sebesar 0,514. Hasil koefisien determinasi total adalah sebagai berikut :

$$
\begin{aligned}
\mathrm{R}^{2} \mathrm{~m} & =1-\left(\mathrm{Pe}_{1}\right)^{2}\left(\mathrm{Pe}_{2}\right)^{2} \ldots \ldots \\
& =1-(0,609)^{2}(0,514)^{2} \\
& =1-(0,371)(0,264) \\
& =1-0,098=0,902
\end{aligned}
$$

Nilai determinasi total sebesar 0,902 mempunyai arti bahwa sebesar 90,2 persen variasi minat beli dipengaruhi oleh variasi gaya hidup, dan sikap, sedangkan sisanya sebesar 9,8 persen djelaskan oleh faktor lain yang tidak dimasukkan ke dalam model.

Tabel 4.

Pengaruh Langsung dan Pengaruh Tidak Langsung serta Pengaruh Total Gaya Hidup (X), Sikap (Y), dan Minat Beli $\left(\mathbf{Y}_{2}\right)$

\begin{tabular}{ccccc}
\hline & $\begin{array}{c}\text { Pengaruh } \\
\text { Variabel }\end{array}$ & $\begin{array}{c}\text { Pengaruh } \\
\text { Langsung }\end{array}$ & $\begin{array}{c}\text { Pengaruh Tidak Langsung Melalui } \\
\text { Sikap } \\
(\text { Y1 })(\boldsymbol{\beta 1} \mathbf{x} \boldsymbol{\beta 3})\end{array}$ & $\begin{array}{c}\text { Pengaruh } \\
\text { Total }\end{array}$ \\
\hline $\boldsymbol{\beta 1}$ & $\mathrm{X} \rightarrow \mathrm{Y} 1$ & 0,793 & - & 0,793 \\
$\boldsymbol{\beta 2}$ & $\mathrm{X} \rightarrow \mathrm{Y} 2$ & 0,682 & 0,166 & 0,848 \\
$\boldsymbol{\beta 3}$ & $\mathrm{Y} 1 \rightarrow \mathrm{Y} 2$ & 0,209 & - & 0,209 \\
\hline Sumber: & Data diolah, 2018 & &
\end{tabular}

Menguji signifikansi pengaruh tidak langsung maka nilai z dari koefisien ab dihitung dengan rumus sebagai berikut :

$$
\begin{aligned}
& S_{b 1 b 3}=\sqrt{(0,793)^{2}(0,103)^{2}+(0,209)^{2}(0,018)^{2}+(0,018)^{2}(0,103)^{2}} \\
& S_{b 1 b 3}=0,081787
\end{aligned}
$$

Keterangan :

Sb1b3 = besarnya standar error tidak langsung

$\mathrm{Sb} 1=$ standar error koefisien $\mathrm{b} 1$

$\mathrm{Sb} 3=$ standar error koefisien b3

b1 $=$ jalur $\mathrm{X}$ terhadap $\mathrm{Y}_{1}$ 
b5 $\quad=$ jalur $\mathrm{Y}_{1}$ terhadap $\mathrm{Y}_{2}$

b1b5 = jalur $\mathrm{X}$ terhadap $\mathrm{Y}_{1}\left(\mathrm{~b}_{1}\right)$ dengan jalur $\mathrm{Y}_{1}$ terhadap $\mathrm{Y}_{2}\left(\mathrm{~b}_{3}\right)$

Untuk menguji signifikansi pengaruh tidak langsung maka menghitung nilai $\mathrm{z}$ dari koefisien ab dengan rumus sebagai berikut :

$$
Z=\frac{b 1 b 3}{S 1 b 3}
$$

$\mathrm{Z}=\frac{(0,7)(0,2)}{0,0}$

$Z=2,0265$ dengan signifikansi 0,042

Oleh karena $\mathrm{Z}$ hitung sebesar 2,026 > 1,96. Artinya sikap $\left(\mathrm{Y}_{1}\right)$ merupakan variabel yang memediasi gaya hidup $(\mathrm{X})$ terhadap minat beli $\left(\mathrm{Y}_{2}\right)$ smartphone Iphone di Kota Denpasar atau dengan kata lain gaya hidup berpengaruh secara tidak langsung terhadap minat beli melalui sikap konsumen smartphone Iphone.

Berdasarkan hasil analisis pengaruh gaya hidup terhadap minat beli diperoleh nilai signifikansi sebesar 0,000 dengan nilai koefisien beta 0,682. Nilai signifikansi $0,000(<0,05)$, mengidentifikasikan bahwa gaya hidup berpengaruh positif dan signifikan terhadap minat beli. Hal ini berarti semakin tinggi gaya hidup, maka minat beli masyarakat meningkat. Berdasarkan hal tersebut maka hipotesis gaya hidup berpengaruh positif terhadap minat beli smartphone Iphone dapat di terima oleh masyarakat di Kota Denpasar.

Hasil penelitian ini mendukung temuan dari Yuliana (2011), Qing et al. (2012), Kusuma dan Suparna (2015), Indrayani dan Nurcahya (2014) yang menyatakan bahwa gaya hidup berpengaruh secara positif dan signifikan terhadap minat beli.

Berdasarkan hasil analisis pengaruh gaya hidup terhadap sikap diperoleh nilai signifikansi sebesar nilai signifikansi sebesar 0,000 dengan nilai koefisien beta 
0,793. Nilai Signifikansi 0,000 $(<0,05)$ mengidentifikasikan bahwa gaya hidup berpengaruh positif dan signifikan terhadap sikap. Hal ini berarti semakin tingginya gaya hidup, maka sikap yang di rasakan masyarakat meningkat. Berdasarkan hal tersebut maka hipotesis gaya hidup berpengaruh posotif terhadap sikap dapat di terima oleh masyarakat di Kota Denpasar. Hal ini menunjukkan semakin gaya hidup seseorang mengikuti trend masa kini maka sikap seseorang dalam membeli smartphone Iphone juga positif.

Hasil penelitian ini mendukung temuan Nurlaily dan Noermijati (2017), Qing et al. (2012), Fahrozi (2015), Fitriani dkk. (2013) yang menyatakan bahwa gaya hidup berpengaruh secara poitif dan signifikan terhadap sikap. Berdasarkan hasil analisis pengaruh sikap terhadap minat beli diperoleh nilai signifikansi sebesar nilai signifikansi sebesar nilai signifikansi sebesar 0,017 dengan nilai koefisien beta 0,209. Nilai signifikansi $0,017 \quad(<0,05)$ mengidentifikasikan bahwa sikap berpengaruh positif dan signifikan terhadap minat beli. Hal ini berarti semakin baik penerapan sikap maka minat beli yang di rasakan masyarakat meningkat. Berdasarkan hal tersebut maka hipotesis sikap berpengaruh positif terhadap minat beli smartphone Iphone dapat di terima oleh masyarakat di Kota Denpasar.

Hasil penelitian ini mendukung temuan dari Nasehifar dan Haghi (2014), Qing et al. (2012), Xie dan Chalpoopirutana (2014), Sigit (2006), Roselina dan Nurcaya (2012) dan Suraputra (2017) yang menyatakan bahwa sikap berpengaruh secara positif dan signifikan minat beli.

Berdasarkan Hasil Uji Sobel menunjukan bahwa hasil tabulasi Z hitung sebesar 2,026 ( > 1,96). Artinya sikap $\left(\mathrm{Y}_{1}\right)$ merupakan variabel yang memediasi 
hubungan antara gaya hidup $(\mathrm{X})$ terhadap minat beli $\left(\mathrm{Y}_{2}\right)$ smartphone Iphone di Kota Denpasar atau dengan kata lain gaya hidup berpengaruh secara tidak langsung terhadap minat beli melalui sikap. Hal ini berarti dengan adanya gaya hidup maka sikap bisa mempengaruhi seseorang untuk berminat membeli smartphone Iphone.

Hasil penelitian ini mendukung temuan dari Tonget al. (2015), Putra dan Sudiksa (2016), Qing et al. (2012), Suraputra dan Warmika (2017) yang menjelaskan bahwa hubungan antara gaya hidup yang di terapkan bersamaan dengan sikap terhadap minat beli akan menunjukkan hasil yang positif dan signifikan.

Implikasi pada penelitian ini di bagi menjadi implikasi teoritis dan implikasi praktis. Implikasi hasil penelitian ini adalah sebagai berikut :

Implikasi hasil penelitian ini berhubungan dengan kontribusinya bagi perkembangan konsep dalam bidang ilmu pemasaran. Hasil temuan penelitian ini memperkuat penelitiam-penelitian sebelumnya yang menunjukan bahwa gaya hidup mempengaruhi sikap terhadap minat beli. Peneliti juga menunjukkan bahwa sikap menjadi mediasi dari hubungan gaya hidup terhadap minat beli.

Gaya hidup berpengaruh terhadap sikap dan minat beli. Ini membuktikan bahwa apabila gaya hidup yang tinggi, makan sikap yang dirasakan konsumen akan meningkat. Gaya hidup yang tinggi juga akan meningkatkan kebutuhan konsumtif dan minat untuk membeli suatu produk. Sikap juga sebagai pemediasi untuk menguatkan pengaruh antara gaya hidup dengan minat beli. Artinya, apabila gaya hidup dan sikap yang diberikan meningkat, maka akan mempengaruhi minat beli konsumen tersebut. 
Implikasi pertama didalam variabel minat beli didapat hasil bahwa indikator "Merek Iphone menjadi pilihan saat membeli smartphone” menjadi indikator yang tertinggi dibandingkan dengan indikator lainnya, yang artinya bahwa secara keseluruhan responden remaja memiliki keinginan membeli smartphone Iphone karena untuk memenuhi kebutuhan gaya hidup yang semakin tinggi menunjukkan bahwa penggunanya sudah mengikuti trend masa kini. Indikator "Konsumen lebih senang membeli smartphone Iphone dibanding merek pesaing" menjadi indikator yang memiliki nilai rata-rata terendah dibandingkan dengan faktor lainnya. Karena smartphone pesaing sudah bisa menawarkan fitur yang hampir sama dengan smartphone Iphone seperti Samsung, Oppo, dan Vivo baik dari segi kamera maupun kecanggihan dari smartphone tersebut. Kesimpulan yang dapat diambil secara keseluruhan sebagaian besar remaja memilih smartphone Iphone menjadi pilihannya karena dapat memenuhi kebutuhan gaya hidup modern dan trend masa kini.

Implikasi kedua didalam variabel sikap di dapat hasil bahwa indikator “Mengetahui manfaat utama dari Smartphone Iphone.” Menjadi indikator yang memiliki nilai rata-rata tertinggi dibandingkan indikator lainnya, yang artiunya bahwa responden remaja memiliki rasa ingin tahu dengan mencari informasi di internet untuk mengetahui manfaat keseluruhan smartphone Iphone tersebut. Agar timbulnya minat untuk membeli smartphone Iphone. "Memiliki pengetahuan mengenai smartphone Iphone merupakan merek terkenal" indikator yang memiliki nilai rata-rata terendah dari lainnya dapat disimpulkan bahwa smartphone Iphone sebaiknya selalu berinovasi agar konsumen selalu merasakan manfaat dari pengunaan 
smartphone Iphone sehingga konsumen merasa bahwa smartphone Iphone adalah merek smartphone yang terkenal saat ini.

Implikasi ketiga didalam variabel gaya hidup di dapat hasil bawa indikator "smartphone Iphone membantu dalam menyelesaikan tugas." Menjadi indikator yang memilki nilai rata-rata tertinggi dibandingkan indikator lainnya, yang artinya bahwa secara keseluruhan remaja menggunakan smartphone Iphone untuk menyelesaikan tugas agar lebih cepat dengan bantuan beberapa fitur aplikasi yang ada di smartphone Iphone seperti Microsoft Word, Microsoft Excel, Powerpoint dan juga fitur aplikasi lainnya dapat mencetak file atau tugas cukup melalui smartphone Iphone menggunakan aplikasi yang bernama AirPrint. "Menggunakan smartphone Iphone untuk membantu berbelanja online" memiliki nilai rata-rata terendah dan dapat disimpulkan bahwa smartphone Iphone di harapkan mampu untuk menciptakan aplikasi yang dapat memenuhi kebutuhan belanja online karna pengguna smartphone saat ini lebih memilih hal yang cepat dan praktis dalam kegunaan smartphone Iphone.

\section{SIMPULAN DAN SARAN}

Gaya hidup berpengaruh positif dan signifikan terhadap minat beli. Hal ini berarti semakin modern gaya hidup dan mengikuti trend masa kini, maka minat beli masyarakat meningkat. Berdasarkan hal tersebut maka hipotesis gaya hidup berpengaruh posotif terhadap minat beli smartphone Iphone dapat di terima oleh masyarakat di Kota Denpasar.

Gaya hidup berpengaruh positif dan signifikan terhadap sikap. Hal ini berarti semakin tingginya gaya hidup modern, maka sikap yang di rasakan masyarakat 
I Putu Febryantha Mantala, Peran Sikap dalam...

meningkat. Berdasarkan hal tersebut maka hipotesis gaya hidup berpengaruh positif terhadap sikap dapat di terima oleh masyarakat di kota Denpasar.

Sikap berpengaruh positif dan signifikan terhadap minat beli. Hal ini berarti semakin positif penerapan sikap terhadap minat beli yang di rasakan masyarakat akan menjadi lebih baik. Berdasarkan hal tersebut maka hipotesis sikap berpengaruh posotif terhadap minat beli smartphone Iphone dapat di terima oleh masyarakat di Kota Denpasar.

Gaya hidup berpengaruh secara tidak langsung terhadap minat beli melalui sikap. Hal ini berarti dengan adanya gaya hidup modern maka sikap yang positif bisa mempengaruhi minat beli smartphone Iphone di Kota Denpasar.

Pihak smartphone Iphone harus lebih meningkatkan fitur-fitur yang baru dan dapat mengikuti trend masa kini sehingga konsumen akan memberikan sikap yang positif dan minat beli yang tinggi terhadap smartphone Iphone.

Pihak smartphone Iphone sebaiknya selalu berinovasi agar konsumen selalu merasakan manfaat dari pengunaan smartphone Iphone sehingga konsumen merasa bahwa smartphone Iphone adalah merek smartphone yang terkenal saat ini. Pihak smartphone Iphone diharapkan mampu untuk menciptakan aplikasi yang mampu memenuhi kebutuhan belanja online karna pengguna smartphone saat ini lebih memilih hal yang cepat dan praktis dalam kegunaan smartphone Iphone.

Hasil penelitian ini diharapkan bisa menjadi refensi tambahan dan untuk memperkuat hasil dari penelitian-penelitian yang berhubungan dengan variabel gaya hidup pada minat beli terhadap sikap sebagai variabel mediasi pada konsumen smartphone Iphone di kota Denpasar. Hasil penelitian ini juga diharapkan bisa 
berguna sebagai bahan pertimbangan, masukan dan informasi bagi konsumen dalam melakukan pembelian smartphone Iphone dan mendorong konsumen untuk lebih bijak dalam melakukan pembelian smartphone Iphone.

\section{REFERENSI}

Barr, S. (2007). Faktors Influencing Environmental Attitudes And Behaviors. Environment and Beha-vior, 39 (4), h: 435-473.

Fahrozi. (2015). Analisis Pengaruh Gaya Hidup dan Sikap Atas Uang dengan Nilai Pribadi Sebagai Moderasi di Kalangan Muda Terhadap Keputusan Pembelian pada Coffee Shop Di Kota Pekanbaru. Jurnal Tepak Manajemen Bisnis, 242 (2).

Indrayani, Linda dan I Nyoman Nurcaya. (2014). Peran Persepsi Kualitas Produk Dalam Memediasi Pengaruh Gaya Hidup Terhadap Niat Beli Handphone Samsung Galaxy Di Kota Denpasar. Jurnal Fakultas Ekonomi Dan Bisnis Universitas Udayana.

Indriani, Farida dan Dini Hendriati. (2009). Studi Mengenai Efektivitas Iklan Terhadap Citra Merek Maskapai Garuda Indonesia. Jurnal Sains Pemasaran Indonesia. Vol. 8. No. 1 . pp. 83-106.

J. Setiadi, Nugroho, SE., MM., (2003). "Perilaku Konsumen Konsep dan untuk Strategi dan Penelitian Pemasaran". Jakarta: Kencana

Kotler dan Amstrong. (2010). Principles of Marketing. 13 Edition. New Jersey: Pearson Prentice Hall.

Kumala, Octaviantika Benazir. (2012). Pengaruh Word of Mouth Terhadap Minat Beli Konsumen Pada Tune Hotels Kuta-Bali. Jurnal Universitas Indonesia.

Kusuma, Ida Bagus Separsa dan Gede Suparna, (2015). Pengaruh Gaya Hidup Dalam Mediasi Pengaruh Demografi Terhadap Niat Beli Sepeda Motor Vespa Piagio. E-Jurnal Manajemen Unud 4, (8)

Leeraphong, A and A. Mardjo. (2013), "Trust and Risk in Purchase Intention through Online Social Network: A Focus Group Study of Facebook in Thailand". Journal of Economics, Business and Management. 1(4) pp. 321-342

Mowen John, C., dan Minor, M. (2012). Perilaku Konsumen Jilid 1, Edisi Kelima (Terjemahan). Erlangga: Jakarta. 
Nasehifar, Vahid., dan Sayed Mohammad SadiqEs-haghi. (2014). Factors Affecting Consumer Attitudes and Their Impact on Purchase Intention of Leather Clothes. Nationalpark-Forschung in der Scheiz, 103 (1), pp: 33-47.

Pandu, Shyntia Devi. (2017). Pengaruh Citra Merek, Kualitas Produk Dan Gaya Hidup Terhadap Keputusan Pembelian Iphone. Jurnal Studi Manajemen Jurusan Manajemen Fakultas Ekonomi Universitas Sanata Dharma Yogjakarta, Vol. 4, No.12, 2017

Porter, L. W.; Steers, R.M.; Mowday, R.T.; \& Boulian, P.V. (1974) Organizational commitment, job satisfaction, and turnover among psychiatric technicians. Journal of Applied Psychology, 1974, 59, 603-609.

Putra, Putu Eka Yusdiawan dan Ida Bagus Sudiksa. (2016). Peran Sikap Dalam Memediasi Hubungan Antara Harga Dengan Niat Beli Smartphone Merek Samsung. E-Jurnal Manajemen Unud, Vol. 5, No. 10, 2016: 6762-6794

Qing, Lobo, Antonio and Chongguang, Li. (2012). The Impact of Lifestyle and Ethnocentrism on Consumers Purchase Intention of Fresh Fruit in China. Faculty of Economics and Management, Huazhong Agricultural University, Wuhan, People's Republic of China.

Riduwan dan Engkos Achmad Kuncoro. (2011). Cara Menggunakan dan Memakai Path Analysis (analisis jalur). Bandung: Alfabeta.

Roselina, Ni Putu Novia dan Nurcaya, I Nyoman. (2012). Pengaruh Sikap Konsumen dan Norma Subyektif Terhadap Niat Beli Mobil Toyota Agya di Kota Denpasar. Jurnal Fakultas Ekonomi dan Bisnis Universitas Udayana.

Sangadji, Etta Mamang dan Sopiah. (2013). Perilaku Konsumen : Pendekatan Praktis Disertai Himpunan Jurnal Penelitian. Edisi pertama. Yogyakarta : Andi.

Saputra, Setiawan Tri, Kadarisman Hidayat, dan Sunarti. (2017). Pengaruh Kualitas Produk Terhadap Keputusan Pembelian Dan Dampaknya Terhadap Kepuasan Konsumen Pengguna Iphone (Survei Pada Mahasiswa Fakultas Ilmu Administrasi Universitas Brawijaya Malang). Jurnal Administrasi Bisnis (JAB), 50 (6), h: 85-95.

Schiffman, L.G dan Kanuk, Lesley L. (2007). Consumer Behavior, New Jersey: Perason Prestice Hall.

Sekaran,Uma. (2003). Research Metods For Business. New Jersey : Jhon Willey \& Sons Inc.

Setiadi, Nugroho J. (2003), Perilaku Konsumen. Kencana. Jakarta. 
Setiadi, Nugroho J. (2010). Perilaku Konsumen. Cetakan 4. Edisi Revisi. Jakarta : Kencana.

Setiadi, Nugroho. (2010). Perilaku Konsumen: Perspektif Kontemporer pada Motif, Tujuan, dan Keinginan Konsumen. Jakarta: Kencana Prenada Media.

Severin, Werner J dan James W. Tankard. (2009). “Teori Komunikasi: Sejarah, Metode, dan Terapan di dalam Media Massa:. Dialihbahasakan Sugeng Hariyanto. Kencana. Jakarta.

Sigit, Murwanto. (2006). Pengaruh Sikap dan Norma Subyektif terhadap Niat Beli Mahasiswa sebagai Konsumen Potensial Produk Pasta Gigi Close Up. Jurnal Siasat Bisnis. 11 (1), h: 81-91.

Sigit, Murwanto. (2006). Pengaruh Sikap dan Norma Subyektif terhadap Niat Beli Mahasiswa sebagai Konsumen Potensial Produk Pasta Gigi Close Up. Jurnal Siasat Bisnis. 11 (1): h: 81-91.

Sumarwan, Ujang. (2002). Perilaku Konsumen: Teori dan Penerapannya dalam Pemasaran. Bogor: Ghalia Indonesia.

Suprapti, Ni Wayan Sri. (2010). Prilaku Konsumen, Pemahaman Dasar, dan Aplikasinya dalam Strategi Pemasaran. Bali: Udayana University Press.

Suraputra, I Made Widya dan I Gede Ketut Warmika. (2017). Pengaruh Gaya Hidup Terhadap Niat Pembelian Sepeda Motor Sport Honda yang Dimediasi Oleh Sikap. E-Jurnal Manajemen Unud, 6 (1), h: 176-203.

Sutisna. (2001). Perilaku Konsumen dan Komunikasi Pemasaran. Bandung: PT Remaja Rosdakarya.

Syafrudin, (2016). Pengaruh Gaya Hidup Terhadap Keputusan Pembelian Handphone Iphone Di Kota Malang. Skripsi Fakultas Ekonomi Dan Bisnis Universitas Muhammadiyah Malang

Tong, Foo Weng.Khin, Aye-aye and Khatibi, Ali. (2015). Impact of Changing Consumer Lifestyles on Intention to Purchasetowards Green and Halal Foods of the Chicken Meat Industry in Malaysia Lokal. International Journal of Marketing Studies, 7 (6), h: 1918-7203.

Wen, Ling-Yu Melody and Li, Shang-Hui. (2013). Consciouness, Ecological Affect, and Purchase Intetion of Green Production. Journal of Organizational Innovation, 5 (4), h: 124-137. 
I Putu Febryantha Mantala, Peran Sikap dalam...

Widjaja, T Bernard. (2011). Lifestyle Marketing: Paradigma Baru Pemasaran Bisnis Jasa dan Lifestyle. PT Gramedia, Jakarta.

Xie, Xizi., \& Sirion Chaipoopirutana. (2014). A Study of Factors Affecting Towards Young Consumers' Purchase Intention of Domestic-Branded Smartphone in Shanghai, Republic of China. International Conference on Business, Law and Corporate Social Responsibility, pp: 31-35.

Yuliana, R. (2011). Pengaruh Gaya Hidup Terhadap Keputusan Pembelian Pakaian Batik Tulis Danar Hadi (Studi Konsumen Wanita Pada Outlet Danar Hadi Diponegoro Surabaya). Jurnal Universitas Negeri Surabaya. 